\title{
Can Information Alone Change Behavior? Response to arsenic contamination of groundwater in Bangladesh*
}

\author{
Malgosia Madajewicz ${ }^{\ddagger}$, Alexander Pfaff ${ }^{\ddagger}$, \\ Alexander van Geen, Joseph Graziano, \\ Iftikhar Hussein, Hasina Momotaj, Roksana Sylvi, \\ Habibul Ahsan \\ Columbia University \\ November 2006
}

\begin{abstract}
We study how effectively information induces Bangladeshi households to avoid a health risk. The response to information is large and rapid; knowing that the household's well water has an unsafe concentration of arsenic raises the probability that the household changes to another well within one year by 0.37 . Households who change wells increase the time spent obtaining water fifteen-fold. We identify a causal effect of information, since incidence of arsenic is uncorrelated with household characteristics. Our door-to-door campaign provides well-specific arsenic levels without which behavior does not change. Media communicate general information about arsenic less expensively and no less effectively.

JEL codes: O12, Q50

Keywords: information, health risk, arsenic, drinking water

Madajewicz, Pfaff, van Geen, Graziano and Ahsan are at Columbia University. Hussein and Momotaj are at National Institute of Preventive and Social Medicine (NIPSOM), Dhaka, Bangladesh.

Sylvi is currently unaffiliated.
\end{abstract}

\footnotetext{
* We are grateful to participants in seminars, two referees and the editor for very helpful comments. Shubham Chaudhuri, Rounaq Jahan and Phil Oldenburg contributed to the development of this research project. We thank the Earth Institute at Columbia for a large start-up grant. We are grateful to Md. Jakariya at the Bangladesh Rural Advancement Committee (BRAC), S.M.A. Rashid at NGO Forum, Bilqis Haque at the Environment and Population Research Center (EPRC), Atiur Rahman and Rathindranath Pal at Unnayan Shamannay, and Jan Willem Rosenboom at UNICEF for their collaboration. We also thank our interviewers.

${ }^{\ddagger}$ Co-lead authors. Corresponding author is Madajewicz mm1174@columbia.edu.
} 


\section{Introduction}

As many as one billion people in the world drink unsafe water (WSCC, 1999). Over two million deaths from diarrhea are estimated to have occurred in 1998, mainly among children (WHO, 1999). People drink unsafe water because they are not informed about the risks to their health and because they lack access to safe water. Providing information is a less expensive and simpler policy than providing safe sources of water. Therefore, it is important to know if and when information alone can induce people to seek safe water with their own resources.

We study how people react to information about concentrations of arsenic in their drinking water in Bangladesh. First, we determine the probability that a person who learns that her well is unsafe seeks another source of water and we estimate a lower bound on the willingness to pay (WTP) for safe water. Second, we compare the effectiveness of a door-to-door information campaign and a campaign based on the media in communicating information about arsenic other than well-specific test results.

One-third or more of the wells in Bangladesh have arsenic concentrations above the Bangladeshi safety standard of 50 micrograms per liter $(\mu \mathrm{g} / \mathrm{L}) .{ }^{1}$ At least 37 million people are consuming unsafe water. (BGS/DPHE 2001) Arsenic contamination surfaced in Bangladesh after a successful health campaign promoted drinking groundwater rather than surface water starting in the 1970s. The change in behavior reduced the incidence of water-borne diseases, but exposed people to arsenic.

Long-term exposure to arsenic causes a variety of potentially lethal health problems whose gestation periods vary from 5 to 20 years. ${ }^{2}$ Since the majority of the population has been using wells since the early 1990's, the country may now be in the early stages of an epidemic described by Smith et al in the WHO Bulletin (2001) as "... the largest case of mass poisoning in history."

A multi-disciplinary team of researchers working with the government's National Institute of Preventive and Social Medicine and four non-profit, non-government organizations (NGOs) provided two

\footnotetext{
${ }^{1}$ The World Health Organization lowered its standard for safe concentrations from 50 to $10 \mu \mathrm{g} / \mathrm{L}$ in 1993 .

${ }^{2}$ See section A.2 of the appendix. Some references are Chang et al (2004), Chiu et al (2004), Hopenhayn-Rich et al (1996), Lokuge et al (2004), Moore et al (1997), Wasserman et al (2004).
} 
types of information in the study area in Araihazar district. ${ }^{3}$ First, we tested the water in each well, labeled the well as safe or unsafe and reported the result to the users of the well. Second, we organized discussions about the dangers of drinking unsafe water. Households in Araihazar and in four control areas, in which we did not provide information, were also exposed to information about arsenic disseminated by the government through TV, radio and newspapers.

Our most striking result is the strong response to the well tests. Sixty percent of people who learn that the well they used before the information campaign is unsafe change to another well within one year. ${ }^{4}$ Only $14 \%$ of people whose baseline well is safe change, and only $8 \%$ of people change in control areas. Controlling for other factors, having an unsafe well increases the probability that the household changes to another well by 0.37 . Ninety-eight percent of people in Araihazar can correctly state whether the baseline well is safe. Few people in control areas claim to know the status of their well. Therefore, the change in behavior in Araihazar appears to be a response to information about one's well.

We find that those who change to another well increase the time they spend walking for water fifteen-fold, by 4.3 minutes for a round trip. The opportunity cost of time is likely to be the main cost borne by those who change to a neighbor's private well or a community well, sources chosen by $76 \%$ of those who changed to another well. ${ }^{5}$ It is the cost on which we base our estimate of a lower bound for the WTP for another source of water.

We argue that we identify the causal effect of information about the baseline well on households' behavior. Our estimates could be biased if households whose wells are unsafe switch due to factors other than arsenic which are correlated with arsenic levels. The source of the arsenic is natural. ${ }^{6}$ Almost any type of rock or soil contains enough arsenic to yield unsafe concentrations in water if released. Arsenic is released when the accumulation of plant matter during the formation of river delta deposits drives

\footnotetext{
${ }^{3}$ The NGOs are Bangladesh Rural Advancement Committee (BRAC), The NGO Forum for Water and Sanitation (NGOF), Environment and Population Research Center (EPRC) and Unnayan Shamannay.

${ }^{4}$ Opar et al (2006) report the same descriptive statistic based on a later survey in Araihazar.

${ }^{5}$ Arsenic concentrations vary greatly within hundreds of feet, therefore a household whose well is unsafe often has neighbors whose wells are safe. (van Geen et al 2002)

${ }^{6}$ See for example Nickson et al (1998), Nickson et al (2000), McArthur et al (2001).
} 
groundwater to anoxia. The process may generate a correlation between soil types and arsenic levels and therefore possibly between arsenic levels and incomes. However, this correlation would not be likely to appear within villages. Wells are located within small, densely inhabited villages. The surrounding fields are fairly uniform geologically, while the dispersion of incomes and wealth within villages is large. We show that levels of arsenic are not correlated with observable household characteristics within villages.

The response to well tests suggests that information alone may result in a rapid and large change in behavior to avoid a risk to health. The change has significantly reduced exposure to arsenic according to data on arsenic concentrations in the urine collected by public health researchers. (Chen et al 2006) Nevertheless, the size and rapidity of the response are surprising since only $6 \%$ of people in our study area have symptoms of arsenic poisoning (Ahsan et al 2006a and 2006b), and the response is costly as reflected in the increased amount of time spent walking for water.

Furthermore, the response contrasts with most examples in the economic literature, which emphasize that behavior changes slowly in response to accumulation of information and the example of other people's behavior. ${ }^{7}$ The context in our paper is different from contexts studied in the literature, therefore an outstanding question is under what conditions a large and rapid response can be expected.

Our second point is that the media campaign disseminates general information about arsenic no less effectively than does our door-to-door campaign and it is orders of magnitude cheaper. However, the media campaign has not led to well testing. Without well-specific information, people in control areas do not know whether their own and their neighbors' wells are safe and they have not sought safe water.

In Section 2, we present a simple model. Section 3 describes the project and the data. In Section 4, we discuss the effect of knowing whether one's well is safe on the decision whether to change to another well and we estimate the WTP to reduce exposure to arsenic. In Section 5, we analyze the difference between the effect of the door-to-door campaign and the media campaign. Section 6 concludes. 


\section{Model}

We provide a simple one-period model which determines how much safe water an individual seeks. ${ }^{8}$ The model suggests a way to measure WTP for avoiding consumption of unsafe water.

An individual maximizes her utility, which is a function of her health, subject to a budget and a time constraint. The measure of health is the number of days of work or school missed because of illness, $h(d, b)$, where $d$ is the effective exposure to arsenic, and b is the amount of medical intervention sought to reduce the effects of arsenic. Effective exposure to arsenic, $\mathrm{d}\left(\mathrm{a}, \mathrm{s}_{\mathrm{q}}, \mathrm{s}_{\mathrm{t}}\right)$ depends on $\mathrm{a}$, the amount of arsenic in the water the individual consumes, $\mathrm{s}_{\mathrm{q}}$, the quantity of safe water which the individual purchases, and $\mathrm{s}_{\mathrm{t}}$, the amount of time which the individual spends obtaining safe water, e.g. by walking further for water. The distinction between $\mathrm{s}_{\mathrm{q}}$ and $\mathrm{s}_{\mathrm{t}}$ allows the cost of obtaining safe water to have components which have different prices, the market price of water and the opportunity cost of time respectively. We can write the number of days missed as $h\left(a, s_{q}, s_{t}, b\right)$.

In general, safe water may require both monetary compensation and an investment of time. In our context, the quantity of safe water purchased may be thought of as water from a new well, which must be installed and maintained, or water from a well belonging to a neighbor, who has to be compensated for the use of the water, or water from a community well, which requires a contribution to the community. However, respondents report that they do not pay money for water, but rather compensate the owner of the well in kind and that the compensation is voluntary and not large. ${ }^{9}$ Therefore, the primary cost of changing to a well which is not one's own is likely to be the opportunity cost of time incurred by having to walk further for water. Seventy-six percent of households who change to another well change to a well which is not their own.

The maximization problem is the following

\footnotetext{
${ }^{7}$ Munshi and Myaux (2002), Conley and Udry (2002), Foster and Rosenzweig (1995), Besley and Case (1994), Munshi (2004), Jalan et al. (2004)

${ }^{8}$ The model is essentially the one-period version of Grossman's (1972) model presented in Freeman (1993).

${ }^{9}$ Respondents may be reluctant to admit monetary payments because of the Islamic injunction against demanding payment for drinking water.
} 


$$
\begin{aligned}
& \max _{s_{q}, s_{t}, b, f, X} U(X, f, h) \\
& \text { s.t. } \quad I+p_{w}\left(T-f-h-s_{t}\right) \geq X+p_{s_{q}} s_{q}+p_{b} b
\end{aligned}
$$

In this problem, $\mathrm{X}$ is a composite, private good purchased by the individual, $\mathrm{f}$ is leisure time, $\mathrm{T}$ is the total amount of time available, $\mathrm{p}_{\mathrm{w}}$ is the wage, $p_{s_{q}}$ is the price of a safe source of water and $\mathrm{p}_{\mathrm{b}}$ is the price of medical services. The expression $\left(T-f-h-s_{t}\right)$ represents the total amount of time spent earning an income.

The first-order conditions for the quantity of safe water purchased and the time spent obtaining safe water are

$$
\frac{\partial U}{\partial h}-\lambda p_{w}=\frac{\lambda p_{s_{q}}}{\partial h / \partial s_{q}}
$$

and

$$
\frac{\partial U}{\partial h}-\lambda p_{w}=\frac{\lambda p_{w}}{\partial h / \partial s_{t}}
$$

where $\lambda$ is the Lagrange multiplier on the budget constraint.

The above maximization problem yields the demand function for $\mathrm{s}_{\mathrm{q}}, \mathrm{s}_{\mathrm{q}} *\left(\mathrm{I}, p_{w}, p_{s_{q}}, p_{b}, \mathrm{a}\right)$ and an analogous one for $\mathrm{s}_{\mathrm{t}}$. Empirically, we will consider one demand function for safe water.

The model also yields an expression for WTP for avoiding arsenic as a function of information observable in our data. The expression below follows directly from the derivation in Freeman (1993), p. 350, using the above first-order conditions.

$$
w_{a}=\frac{\partial h / \partial a}{\partial h / \partial s_{q}} p_{s_{q}}=p_{w} \frac{d h}{d a}+p_{s_{q}} \frac{\partial s_{q}^{*}}{\partial a}+p_{w} \frac{\partial s_{t}^{*}}{\partial a}+p_{b} \frac{\partial b^{*}}{\partial a}-\frac{\partial U / \partial h}{\lambda} \frac{d h}{d a}
$$

where asterisks denote demand functions. The left-hand side is the marginal WTP for a reduction in exposure, because one can show that marginal WTP is equal to the marginal rate of substitution between pollution and any input which determines health, multiplied by the price of that input. Cost minimization in the production of health requires that the values of marginal products of all inputs be equal. 
The first four terms on the right-hand side of expression (3) are observable in principle. They can be approximated with information about observed changes in days spent ill due to exposure to arsenic, expenditures on safe water, the value of time spent walking for safe water and expenditures on medical assistance. Applying data to expression (3) should yield an underestimate of the marginal WTP. The last term, which is unobservable, is positive since $\frac{\partial U}{\partial h}<0$. Therefore, the true marginal WTP is higher than the measured one.

Our data allows only a partial estimation of what expression (3) suggests. We estimate the WTP for the average change in arsenic resulting from a change to a different well by a household whose baseline well is unsafe. We do not know to which well the household changed for enough households to determine the resulting change in arsenic levels.

Second, we estimate only two components of WTP, the value of additional time spent walking for water as a result of the change to another source and the value of this and all other costs of the new source as reflected in the difference between household expenditures of those households who change and those who do not among those whose baseline wells are unsafe. We may underestimate WTP, because we do not observe the first and the fourth terms on the right-hand side of (3) in addition to the last term.

\section{Project and data}

The project is a joint effort by earth scientists, public health researchers and economists to study the arsenic problem in Bangladesh and to help design policy responses. The study took place in a $25 \mathrm{~km}^{2}$ section of the Araihazar district, $20 \mathrm{~km}$ south-east of Dhaka, with a population of 70,000 and with 6500 wells in 54 villages. We also conducted surveys in a subdistrict of each of four other districts in the country in order to provide a control for the analysis in Araihazar. The other subdistricts are Jessore Sadar in Jessore district, Nikli in Kishoreganj, Tangail Sadar in Tangail and Ghior in Manikganj.

In Araihazar, we provided three main pieces of information: the results of well tests, general information about the health consequences of drinking water which has unsafe levels of arsenic, and the 
results of a health exam. The earth scientists tested every one of the 6500 wells and labeled each with a picture denoting whether the well is safe or not and the level of arsenic. ${ }^{10}$ (van Geen et al 2003) A well was labeled unsafe if the concentration of arsenic exceeded $50 \mu \mathrm{g} / \mathrm{L}$. Contemporaneously with the well tests, the public health team interviewed 4,803 married couples and 2140 other married individuals, telling respondents whether the well which they primarily use for drinking water is safe and the level of arsenic in it. They also conducted a health exam, which included a urine and blood sample, and told each respondent if they had symptoms of an arsenic-related illness. (Ahsan et al 2006a and 2006b, Parvez et al 2006)

After the public health interviews, a team of three educators held meetings in each neighborhood to communicate information about arsenic through skits, songs and conversation using materials designed for an illiterate audience. The meetings were conducted during working hours. Thirty-one percent of the people in our sample attended a meeting. The information included health problems which arise from drinking water with unsafe levels of arsenic, the fact that these are not contagious, the fact that commonly known treatments of water, such as boiling, do not remove arsenic, and an explanation of the labels on the wells. They suggested that people whose wells are unsafe switch to safe wells, exhorted those with safe wells to allow others to use them and warned against using surface water unless people boil it.

The data for this paper is from a survey which we carried out six to twelve months after the education campaign and from the earlier public health survey. From the public health survey, we know the baseline well for each household and whether or not they had heard of the arsenic problem before our information campaign. All other data documents conditions after information was provided.

In our post-education-campaign survey, we interviewed 2680 individuals who responded to the public health survey. The sample for the public health survey consisted of randomly chosen married couples or individuals at each of the 6500 wells. We randomly selected 2000 wells and then randomly

\footnotetext{
${ }^{10}$ The picture denoting whether the well is safe is understandable to the $55 \%$ of the population who are illiterate.
} 
chose one of the couples from the public health sample who use that well. Our sample consists of 1089 married couples, 414 married women and 87 married men. ${ }^{11}$

We asked questions in the following categories: characteristics of the household and its members, what the respondent knows about the arsenic problem, which source of water the household currently uses, respondent's social networks, household expenditures on food and non-food items, savings, remittances and assets. Tables 1 and 2 present descriptive statistics of selected variables.

During the last months of our survey in Araihazar, we collected information in control areas, in which neither we nor anyone else had tested all wells nor conducted a door-to-door education campaign. We interviewed 200 married couples in Jessore Sadar and 100 each in Tangail Sadar, Nikli and Ghior. Jessore Sadar includes one of the largest cities in Bangladesh, Jessore. In this area, we selected 3 city neighborhoods, 4 mixed urban/rural neighborhoods and 3 villages. All were chosen randomly from a list of neighborhoods and villages. We interviewed 20 couples randomly chosen in each neighborhood or village. In all other areas, we randomly chose 5 villages from the list of all villages and randomly chose 20 couples in each village.

We collected the same categories of information in each control area as in Araihazar. We did not know which well the household was using six to twelve months earlier, i.e. when households in Araihazar received information about their wells, so we asked each respondent to recall whether they had changed to a different source of water in the last twelve months. We provide a time line of the project in section A.1 of the appendix.

\section{Effect of information on behavior}

We estimate the effect of information that the baseline well is unsafe on whether or not the respondent obtains drinking water from another well. The alternative sources of water available to people whose wells are unsafe are constrained by the short period of time which has elapsed since information

\footnotetext{
${ }^{11}$ We could not interview the couple at every well, nor could we always interview both members of the couple.
} 
was provided. The great majority of wells in Araihazar are privately owned by households and another household's private well is the most readily available option. Close to $90 \%$ of households in our study area live within 100 meters of a safe well, even though only $46 \%$ of wells are safe. (van Geen at al 2002) Among those who change to another well in our sample, $63 \%$ change to a neighbor's private well, $24 \%$ install their own new well and $13 \%$ change to an existing community well.

We estimate the equilibrium relationship between information and behavior. Our hypothesis is that information about one's well affects one's demand for another source of water. However, we may be underestimating the demand effect since the information is also correlated with supply. Arsenic levels are positively correlated, therefore a household whose well is unsafe is more likely to have neighbors whose wells are unsafe and therefore has fewer safe wells in the vicinity. We include the percent of neighbors within a 100 meter radius whose wells are unsafe and their average arsenic in the regression to control partly for the supply effect.

We estimate the effect of information using only Araihazar data. The data are sufficient to obtain an unbiased estimate as long as the status of the baseline well and whether the household knows the status are orthogonal to household characteristics which may affect the decision to change to another well. ${ }^{12}$ Almost all households in Araihazar know whether their own well is safe or not, therefore we only need to establish that whether a well is safe is uncorrelated with household characteristics.

Although the distribution of arsenic in Araihazar and elsewhere in Bangladesh is highly variable spatially, this variability is geological and unlikely to be related to any characteristics of the respondents. ${ }^{13}$ One potential relationship to patterns of human activity is based on the fact that the amount of arsenic released in shallow groundwater is related to the age of groundwater. ${ }^{14}$ Age, in turn, appears to be related to the permeability of nearby soils. ${ }^{15}$ In principle, this relationship could generate a correlation between arsenic contamination and patterns of cultivation, and therefore perhaps income and wealth. For

\footnotetext{
${ }^{12}$ These conditions do not hold in the data from control areas, where few people claim to know the status of their wells and they are a self-selected group.

${ }_{13}^{13}$ BGS/DPHE (2001), van Geen et al (2003), Yu et al (2003)

${ }^{14}$ Stute et al (2006)
} 
instance, a high-arsenic village surrounded by fine-grained, impermeable fields could conceivably be better off because less irrigation water is needed to produce rice. In rice paddies cultivated in sandy and therefore permeable fields, irrigation pumps have to run considerably longer than in clayey fields to compensate for the water lost to percolation. (van Geen et al., 2006) However, the mechanism would yield a positive correlation between expenditure or assets and arsenic, while we find a negative correlation when we consider variation across villages. Furthermore, the mechanism does not suggest a reason why arsenic may be correlated with household characteristics within villages. Villages are generally surrounded by fields with fairly uniform geological characteristics and therefore irrigation requirements, while variation in expenditure and assets is larger within villages than across them.

A second potential source of correlation is that wealthier households may be more likely to have deeper wells and depth of well is correlated with the level of arsenic. However, average arsenic concentrations increase with depth for depths less than 15 meters, which is the median in our study area, and they decrease with depth for larger depths. Any potential effect of this relationship on our results is unclear. Also, we control for income and assets in the regressions.

We supply evidence that arsenic is not correlated with observable household characteristics within villages in Table 3. The first two columns show means of various characteristics for respondents whose wells are safe and those whose wells are unsafe. Respondents whose wells are unsafe on average have slightly lower household expenditures, lower assets, and they are slightly older. However, in the regression reported in column 3, in which we include village fixed effects, whether or not a well is safe is correlated only with age. The F test for whether the coefficients on all independent variables except the village fixed effects are zero has a $\mathrm{p}$ value of 0.33 .

Two factors which may be correlated with the status of the baseline well may result in a different response to information about the well in areas other than Araihazar. First, the response to unsafe wells may be different in areas in which more people have health problems due to arsenic than in Araihazar. Second, the distribution of arsenic in the area may affect a household's decision whether or not to change

${ }^{15}$ Aziz et al (2006), Weinman et al (2006) 
to another well. If neighbors influence each others' behavior, then the percentage of neighbors who have unsafe wells may affect the decision. We control for this effect partly using information about arsenic in wells belonging to neighbors who live within 100 meters.

\subsection{Methodology}

We estimate an OLS regression in which the binary outcome is whether respondent $\mathrm{i}$ in village $\mathrm{j}$ changes to another well or not. Our estimator of the effect of information is the coefficient on the binary variable which indicates whether the respondent's baseline well is safe. Since the independent variable of interest is binary, OLS provides a non-parametric estimator, whereas probit does not.

We also compare the probability that the respondent changes to a different well in a restricted range of arsenic levels, i.e. just below and just above the threshold of $50 \mu \mathrm{g} / \mathrm{L}$, above which the well is labeled unsafe. If a concern remains that levels of arsenic are correlated with respondents' unobserved characteristics, then respondents whose wells have similar arsenic levels should have similar characteristics. ${ }^{16}$ Therefore, a large difference in behavior between households whose baseline wells are just below the safe threshold and those whose wells are just above it should be due to the information value of the safe threshold and not other characteristics correlated with arsenic levels. Even if this assumption does not hold, but the relationship between characteristics and arsenic levels is smooth, then the effect of the threshold should constitute a valid estimate of the effect of information when we control smoothly for arsenic levels.

\section{$4.2 \quad$ Results}

The most remarkable result which we document is that $60 \%$ of the respondents in Araihazar whose baseline wells are unsafe change to a different well. Only $14 \%$ of households whose wells are safe change and only $8 \%$ of people change in control areas over the same period of time. ${ }^{17}$ In Araihazar, $98 \%$ of the 2,071 respondents who answered the question can correctly state whether the baseline well is safe

\footnotetext{
${ }^{16}$ Angrist and Lavy (1999), Chay and Greenstone (2005), Cook and Campbell (1979)

${ }^{17}$ Households whose wells are safe or those who do not know whether their wells are safe may change, because the well malfunctions or the quality of the water deteriorates. Opar et al (2006) document broken wells.
} 
or not and the information is publicly available on well labels. In control areas, $20 \%$ of respondents claim to know the status of the well they were using 12 months before, but we do not know whether their information is based on well tests or if they are simply claiming to be informed. ${ }^{18}$ Also, the information is not public; therefore people cannot easily find a safer well. These statistics strongly suggest that households in Araihazar whose wells are unsafe and who change are responding to information about arsenic in their wells.

Having an unsafe well increases the probability of changing to another well by 0.45 , relative to the probability of changing when the baseline well is safe, when we do not control for the continuous level of arsenic in the full sample, as shown in column 1 of Table 4 . The effect is 0.37 when we do control for the level, as shown in column 3. The estimates remain almost the same if we do not control for household characteristics, as columns 2 and 4 show. The stability is consistent with the evidence that arsenic is uncorrelated with respondent characteristics within villages.

The behavior of those households whose baseline wells have arsenic concentrations just below the safe threshold of $50 \mu \mathrm{g} / \mathrm{L}$ is significantly different from the behavior of those whose wells are just above this threshold, as we show graphically in Figure 1. The figure reports a non-parametric regression of whether or not the respondent changes to another well on arsenic concentration in the baseline well for households whose baseline wells have arsenic levels between 0 and $100 \mu \mathrm{g} / \mathrm{L}$. The probability of changing increases sharply at the safe threshold of $50 \mu \mathrm{g} / \mathrm{L} .{ }^{19}$ Thus, people seem to be responding mainly to the categorization of wells as safe or unsafe, despite the fact that arsenic concentrations just below the threshold are unlikely to be much safer than those just above it.

In a regression, having an unsafe well increases the probability of changing for households whose baseline wells have arsenic levels between 0 and $100 \mu \mathrm{g} / \mathrm{L}$ by 0.40 if we do not control for continuous

\footnotetext{
${ }^{18}$ Eighty-eight percent of respondents in control areas who claim to know the status of their wells say that their wells are safe, while on average $65 \%$ of wells in control areas are safe.

${ }^{19}$ The upturn seems to occur just below $40 \mu \mathrm{g} / \mathrm{L}$ when the degree of the polynomial approximation in the regression is low. However, as the degree increases, the shape of the line between 40 and $50 \mu \mathrm{g} / \mathrm{L}$ begins to resemble the fluctuations below $40 \mu \mathrm{g} / \mathrm{L}$, with a sharp turn upward at $50 \mu \mathrm{g} / \mathrm{L}$.
} 
levels of arsenic, as reported in column 5 of Table 4 . The effect in the 25 to $75 \mu \mathrm{g} / \mathrm{L}$ range is 0.35 , in the 35 to $65 \mu \mathrm{g} / \mathrm{L}$ range it is 0.29 and in the 40 to $60 \mu \mathrm{g} / \mathrm{L}$ range it is $0.19 .{ }^{20}$ These are all significant.

The effect of having an unsafe well in the 0 to $100 \mu \mathrm{g} / \mathrm{L}$ range of arsenic is 0.25 if we control for the continuous levels of arsenic, as shown in column 6 of Table 4 . It is 0.23 in the 25 to $75 \mu \mathrm{g} / \mathrm{L}$ range and significant. It is -0.03 in the 35 to $65 \mu \mathrm{g} / \mathrm{L}$ range and -0.05 in the 40 to $60 \mu \mathrm{g} / \mathrm{L}$ range, and not significant. One interpretation of these results is that the effects of the level of arsenic and the safe threshold may become more difficult to distinguish statistically as the range of arsenic narrows.

We also tested the difference between the effect of an increase in arsenic from $30 \mu \mathrm{g} / \mathrm{L}$ to $40 \mu \mathrm{g} / \mathrm{L}$ and the increase from $40 \mu \mathrm{g} / \mathrm{L}$ to $50 \mu \mathrm{g} / \mathrm{L}$, and several other pairs of intervals of ten $\mu \mathrm{g} / \mathrm{L}$ each below and above the safe threshold. The difference in behavior is statistically significant only between the intervals of $40 \mu \mathrm{g} / \mathrm{L}$ to $50 \mu \mathrm{g} / \mathrm{L}$ and $50 \mu \mathrm{g} / \mathrm{L}$ to $60 \mu \mathrm{g} / \mathrm{L}$. This again suggests that the effect of the safe threshold is not due to unobservables which are correlated with arsenic.

Respondents self-report whether they changed to another well or not. One may be concerned that people whose wells are unsafe are more likely to report that they changed to another well even if they do not in order to please the interviewers. Two pieces of evidence suggest that our result is not biased. First, urinary arsenic declined by $39 \%$ on average in those with unsafe baseline wells who report that they switched, while it declined by $13 \%$ on average in those who report that they did not switch. ${ }^{21}$ Second, we asked people whose wells are safe how many households began to use their wells after being informed about arsenic. The report should underestimate the number who changed since it does not reflect the number of those who installed new wells or who changed to a community well. On average, two households began to use each safe well. This implies a larger percentage of households with unsafe wells switching to other wells than we find.

Above, we explain behavior with the actual arsenic concentration in the well, not what the household believes it to be. The increase in probability of switching predicted by whether the respondent

\footnotetext{
${ }^{20}$ The last two estimates are based on 212 and 114 observations, respectively. These samples have 10 observations per village on average.
} 
thinks the baseline well is unsafe is 0.48 in a regression with continuous arsenic, village fixed effects and other controls. Those who are wrong about the status of the well are overwhelmingly more likely to have an unsafe well; out of 50 people who are wrong 43 have unsafe wells and 7 have safe wells.

The change in behavior is remarkable, since few people have personal experience which tells them that the water is unsafe. Only $6 \%$ of people in our sample know of someone who has either fallen ill or died as a result of arsenic exposure. In addition, changing to another source of water is costly.

We analyze who among the respondents with unsafe baseline wells is more likely to change to another well in order to determine which households require assistance in securing access to safe water. ${ }^{22}$ People are no more likely to change as the level of arsenic in the well increases until the level of arsenic reaches $300 \mu \mathrm{g} / \mathrm{L}$. The finding is troubling since long-term exposure to concentrations of $250 \mu \mathrm{g} / \mathrm{L}$ for example, is far more dangerous than is exposure to levels of $55 \mu \mathrm{g} / \mathrm{L}$ for example.

The household is more likely to change to another well if more neighbors who live within 100 meters have safe wells. Also, family networks appear to play a large role in the decision whether or not to change to another well. The probability that people who own their well switch is 0.22 less than is the probability that people who use wells owned by non-relatives switch. The probability that someone who uses a well owned by a relative within the family compound, called a bari, switches is 0.14 less. Both of these results hold when we control for the distance to the well, thus reflecting an effect other than distance. Furthermore, those who have safe wells report that $93 \%$ of other people using their wells are relatives. People seem to be reluctant to use the wells of neighbors who are not relatives.

People in the lowest quartile of asset ownership seem to be disadvantaged in terms of access to safe water. The probability that a respondent in the lowest quartile changes to another well is 0.11 smaller than is the probability for a respondent in the second quartile.

\footnotetext{
${ }^{21}$ The difference is significant with a $\mathrm{p}$ value close to 0 . (Chen et al 2006)

${ }^{22}$ The results are available from the authors.
} 
Secondary and higher education increase the probability of changing relative to no education, but primary education does not. ${ }^{23}$ The respective increases in probability are .15 and .18 . More educated people may know more about the risks posed by arsenic, as we report in section 5.2, and/or they may evaluate those risks differently conditional on being informed. Also, education could affect one's social status and thereby access to others' wells. Jalan et al (2004) find that education has a large effect on the decision to purify drinking water. They interpret education as a proxy for how informed people are. In our sample, there is almost no variation in how informed people are about the safety of their wells, therefore the effect of education is conditional on having this piece of information.

\subsection{Willingness to pay for safe water}

We estimate two components of the WTP for a reduction in exposure to arsenic in the Araihazar sample: the opportunity cost of time, and all other costs associated with changing to another well. Those who change to someone else's well or a community well have to walk farther for water. The time is likely to have an opportunity cost in terms of foregone income or housework. Furthermore, use of someone else's well or a community well may require either explicit payments or implicit compensation in the form of helping to maintain the well or otherwise assisting the owner of the well. Those who install their own wells pay for the cost of installation and maintenance.

We estimate the effect of changing to another well on the additional time that respondents spend walking for water and, separately, on household expenditure. If labor markets were perfect, the cost of the additional time spent walking for water would appear in foregone earnings and therefore in reduced expenditure or savings. However, in Bangladesh, women walk for water and employment opportunities for women are limited. The additional time women spend walking may not appear in reduced expenditure or savings unless income-earning household members have to work less and help at home more as a

\footnotetext{
${ }^{23}$ Primary education consists of years $1-5$, secondary $6-10$, and higher of years 11 and up.
} 
result. Thus, WTP may actually be a sum of the value of additional time spent walking and any effect on expenditure, where the latter reflects the monetary costs of the source.

The two components do not include other dimensions of WTP for reduction in exposure and therefore they are lower bounds. They ignore the costs of seeking medical remedies. Few people in Araihazar incurred these, therefore they would not be reflected in expenditure. Our estimates also ignore costs reflected in reduced savings and they do not account for the disutility of being ill. ${ }^{24}$

\subsubsection{Methodology}

The following is the regression model which estimates the effect of changing to another well on additional time spent walking for water. The model for the effect on a household's monthly per capita expenditure is identical except for the dependent variable.

$$
\begin{aligned}
t_{i j} & =s_{i j} \kappa+\mathbf{x}_{\mathbf{i j}} \boldsymbol{\alpha}+\mathbf{v}_{\mathbf{j}} \varphi+\varepsilon_{i j} \\
s_{i j} & =a_{i j} \delta+\mathbf{x}_{\mathbf{i j}} \boldsymbol{\alpha}+\mathbf{v}_{\mathbf{j}} \varphi+v_{i j} \\
s_{i j} & =1 \quad \text { if } \mathrm{i} \text { in village } \mathrm{j} \text { changes to another well } \\
& =0 \quad \text { otherwise }
\end{aligned}
$$

The dependent variable, $t_{\mathrm{ij}}$, is the difference between the length of time respondent $\mathrm{i}$ in village $\mathrm{j}$ walks for water now and the length of time she walked to the baseline well. It is zero for those respondents who did not change to another well. The vector $\mathbf{a}_{\mathbf{i j}}$ contains the indicator for whether the baseline well is safe and the level of arsenic in the baseline well. The vector $\mathbf{x}_{\mathbf{i j}}$ contains household and respondent characteristics and characteristics of the baseline well. The vector $\mathbf{v}_{\mathbf{j}}$ contains village fixed effects. The errors in (4) and (5), respectively, are $\varepsilon_{\mathrm{ij}}$ and $v_{\mathrm{ij}}$.

We assume that the errors, $\varepsilon_{\mathrm{ij}}$ and $v_{\mathrm{ij}}$, are correlated. The motivation to seek safe water may be correlated with unobservable characteristics, e.g. entrepreneurial spirit or utility derived from health, which may also affect one's relationship with the neighbors and/or one's status in the community and therefore the distance to an available safe well. When expenditure is the left-hand-side variable, there is

\footnotetext{
${ }^{24} \mathrm{We}$ do not use the data on savings since it may have large errors. The question required the respondent to recall the amount saved over the previous year, which is a long recall period.
} 
also a simultaneity problem caused by the fact that wealthier households are more likely to be able to afford their own new well.

Whether or not the respondent's baseline well is safe and the level of arsenic in this well serve as instruments for changing to a different well. When expenditure is the dependent variable, arsenic may not satisfy the exclusion restriction if respondents exposed to high levels of arsenic suffer health problems which affect expenditure. In this case, the impact of changing to a different source may actually be the effect of the health shock on expenditure. However, arsenic-related medical expenditures are unlikely to affect our results. Among the few people who had arsenic-related symptoms at the time of the survey, even fewer had sought any medical attention, partly because no medical services were available until the public health team established a clinic towards the end of our survey.

The coefficient of main interest, $\kappa$, should be the effect of changing to another well on those households whose baseline wells are unsafe. ${ }^{25} \mathrm{We}$ expect the effect to be positive for the additional time spent walking and negative for expenditures, since we do not include in expenditures money spent on water and expenditures on medical interventions have been limited if any.

In a specification in which only the binary indicator for whether the well is unsafe serves as the instrument, the instrumental variable estimator can be interpreted as a difference-in-difference estimator. It yields an estimate of the difference in time spent walking for water between those households who changed to another well and those who did not among those households exposed to unsafe levels of arsenic minus this difference among those households whose baseline wells are safe.

\subsubsection{Results}

The mean time spent walking to the baseline well is .13 minutes and the median is 0 minutes. Only $5 \%$ of respondents walk more than 1 minute, with 6 minutes being the longest time. After our information campaign, the mean time is 1 minute, the median is still 0 , but $32 \%$ of the sample walk 1 minute or more and the maximum time is 20 minutes.

\footnotetext{
${ }^{25}$ The coefficient should be an estimator of the effect of treatment on the treated. Wooldridge (2002), p.632
} 
Changing to another well on average raises the time the respondent walks one way for water by 2.15 minutes, as we report in the third column of Table 5. Women bring water several times a day, therefore an increase of 4 minutes in the round trip is large, especially relative to the time they had to devote to the activity before.

We also examine the effect in a sample of households whose baseline wells have arsenic concentrations close to the safe threshold, between 0 and $100 \mu \mathrm{g} / \mathrm{L}$. Additional time spent walking rises sharply at the safe threshold of $50 \mu \mathrm{g} / \mathrm{L}$, as Figure 2 shows. In a regression, the effect of changing to another well in this range is a slightly smaller increase in time of 1.82 minutes, as shown in column 6 of Table 5. The result for households whose arsenic levels are between 25 and $75 \mu \mathrm{g} / \mathrm{L}$ is similar.

Changing to a different well does not have a significant impact on expenditure, as the eighth column in Table 5 shows. The result may suggest that labor markets are indeed imperfect, so people can pay for a new source of water with time but not money. However, it may also mean that people are drawing down savings rather than reducing expenditures.

We can obtain a lower bound on respondents' WTP for a reduction in exposure to arsenic by valuing the increase in the time spent walking for water at an appropriate wage. However, a market wage would be highly inaccurate since women obtain the water and their employment opportunities are limited. We do not have the data to estimate a household production function. The following exercise is purely illustrative. The average male wage in our data is 30 taka per hour. Assume that women walk for water once for every meal, i.e. 3 times a day, and value their time at half the male wage. Then the implied WTP per household is 90 taka per month, or about $\$ 6.90$ if converted at a purchasing power rate for $2004 .{ }^{26} \mathrm{~A}$ World Bank report cites similar estimates of WTP for arsenic-free water, between 125 and 162 taka per household per month. ${ }^{27}$ (Ahmad et al 2002, p. 12)

\footnotetext{
${ }^{26}$ The rate, 13 taka for one U.S. dollar, is from the World Bank website.

${ }^{27}$ The report focuses on the results of a contingent valuation survey. However, it also provides WTP estimates based on costs of obtaining safe water incurred by households, which are the figures we cite. They note that the increase in time spent obtaining water is the main cost, but they do not provide the wage at which they value the time.
} 
The estimate of WTP potentially enables us to conduct a preliminary cost-benefit analysis of our information campaign. However, our project involved costs associated with a large, multidisciplinary research project which would not be incurred by an intervention designed only to inform. We can obtain an underestimate of the costs from two components. The cost of wages necessary to bring general information about arsenic to our entire study area was $\$ 9000$, which is $\$ 0.77$ per household. The cost of a test of well water for arsenic is $\$ 0.50 .^{28}$ These two costs ignore the cost of materials needed to communicate the general information, the cost of wages required to conduct a well test, and the cost of well labels. The sum of the two one-time costs is less than the per month WTP for another source of water, which suggests that the benefit of the information provided exceeded the cost.

\section{Comparison of two information campaigns}

We determine whether the door-to-door information campaign carried out in Araihazar contributed to the amount of general information which people have about the arsenic problem over and above the government media campaign. Both households in Araihazar and in the control areas were exposed to information about the dangers associated with drinking water contaminated with unsafe levels of arsenic transmitted through TV, radio and newspapers.

\subsection{Methodology}

We consider whether people in Araihazar are more aware that the arsenic problem exists than are people in control areas, and whether they are more likely to know that boiling water does not remove arsenic and that diseases caused by arsenic are not contagious. ${ }^{29}$ The main independent variable of interest is the treatment variable which takes the value one if the person resides in Araihazar and 0 if she resides in a control area.

\footnotetext{
${ }^{28}$ This cost is based on a test with a portable field kit, not a laboratory test.

${ }^{29}$ The misperception that skin conditions caused by arsenic are contagious causes considerable hardship. Reports that women who are affected are abandoned by their husbands and even banished from their villages are common.
} 
Simple OLS estimates may be biased since we only have one treatment region, four control regions and none of them were chosen randomly. Araihazar was chosen for its accessibility from the capital, Dhaka. The control areas are much farther away from Dhaka. They were chosen from among areas in which our partner NGOs were planning to implement arsenic awareness programs in the future. Table 2 compares a number of characteristics of households in Araihazar and in control areas. Monthly per capita household expenditure in Araihazar does not differ from the average for the control areas. However, the average Araihazar household has less per capita wealth in assets and its adult residents have two fewer years of education. If education or assets are correlated with unobservable characteristics which make people more informed, then the estimate of the treatment effect in Araihazar may be biased downward. On the other hand, the proximity of Araihazar to the capital may bias our results toward finding a bigger treatment effect than is really due to our information campaign.

In order to address the bias, we calculate estimates based on propensity score matching. We report a range of estimates obtained using several approaches: kernel-based matching method using the Gaussian kernel, nearest neighbor matching with equal weights placed on the nearest neighbors in case of a draw, and stratification matching, which yields the average of treatment effects calculated within the blocks of observations in which treatment and control observations do not differ with respect to any observables included in the analysis. ${ }^{30}$ No one of these approaches seems to be a priori preferable to the others. In all cases standard errors were obtained by bootstrapping.

Propensity score estimators have been found to perform well when the same data sources are used for treatment and control groups, the two groups reside in similar economic environments and a rich set of pre-treatment variables is available to estimate the probability of treatment. (Heckman et al 1997, 1998) The first condition certainly holds in our data. The second is less satisfied since some control areas are more urban and some more rural than Araihazar and Araihazar is more industrialized than the others. Also, we collected the data after the treatment. However, we have a number of variables which could not

\footnotetext{
${ }^{30}$ Dehejia (2002), Heckman (1997) and (1998), Smith and Todd (2001)
} 
have been affected by the treatment such as age, gender, education, household size and number of relatives who live in the area. We also use household expenditure and assets to obtain the propensity score, since they could have been affected by treatment only if the household changed to another well and we find that changing to another well does not affect them.

\subsection{Results}

Ninety-nine percent of respondents in Araihazar are aware that well water may be contaminated with arsenic, while $84 \%$ of people in control areas are aware. According to propensity score estimates, the probability that a resident of Araihazar is aware is higher than is the probability for a resident of a control area by 0.20 with the kernel method and the nearest neighbor matching method, reported in column 3 of Table 6 , and by 0.21 with the stratification method. All estimates are significant at $1 \%$.

Fifty-two percent of respondents in Araihazar know that boiling water does not remove arsenic and $43 \%$ know that diseases caused by arsenic are not contagious. The respective percentages in control areas are $62 \%$ and $60 \%$. The probability that a resident of Araihazar knows that boiling water does not remove arsenic is lower by 0.04 , which is significant at $5 \%$, according to the kernel method and it is the same as the probability for a resident of a control area according to the other two methods. The results for the nearest neighbor method are in column 5 of Table 6 . The probability that a resident of Araihazar knows that arsenic-related diseases are not contagious is lower by 0.12 according to the kernel and stratification methods and by 0.1 according to nearest neighbor. These estimates are significant at $1 \%$.

More people in Araihazar appear to be aware of the arsenic problem than in control areas, but fewer are informed about the other two issues. The small difference between the effect of our campaign and the effect of the media is surprising given the intensive presence of our project in Araihazar and the limited reach of the media. People in Araihazar spoke to researchers who were testing wells, researchers who were conducting physical exams, and interviewers, and they saw project staff walking around most days. The presence of foreigners working for a well-known U.S. university is very noticeable to people in rural areas. Also, people in Araihazar learned whether their own well is safe or not, which considerably 
raised the value of knowing whether arsenic is a serious enough danger to be avoided or not. Finally, ownership of televisions and radios is far from universal and only about $15 \%$ of people read newspapers.

The benefit of adding the door-to-door information delivery to a media one does not seem to justify the large cost of the former for the purpose of delivering general information. ${ }^{31}$ We do not know how effective the door-to-door campaign would have been without the media one. In Araihazar, 97\% of respondents report learning about arsenic from our project staff, while $76 \%$ of people in control areas report that they learned about arsenic from the media, $72 \%$ of them from the TV. This suggests that the door-to-door campaign may have attained the same result by itself as it did in addition to the media, but even in this case the media are more cost-effective.

The weakness of the media campaign is that it is not sufficient to change behavior. It has not induced people to test their wells in large numbers. ${ }^{32}$ Well tests provide two crucial pieces of information. The first is whether or not the person's own well is safe and therefore whether the person faces a risk. The second is information about alternatives for reducing the risk, i.e. which of the surrounding wells are safe. Without these pieces of information, behavior does not change. ${ }^{33}$ However, we do not know whether the difference in behavior in Araihazar and the control areas is due only to the well tests. A media campaign supplemented with a well testing program may not elicit a similar change in behavior if our door-to-door campaign helped to persuade people that the arsenic threat is serious enough to warrant costly action.

We studied the determinants of being informed in order to identify categories of people who did not benefit from the information campaigns. The determinants are similar in Araihazar and in control areas. ${ }^{34}$ The most striking results are the importance of education and lack of importance of household

\footnotetext{
${ }^{31}$ The cost of wages required to bring information door-to-door throughout the country once in the course of a year would be about $\$ 17$ million, using the wage which our project paid. This ignores all other costs involved.

${ }^{32}$ We do not know whether the media campaign has not led to well testing because people do not seek the tests or because the tests are not available or are too expensive. In principle, the media inform people that local offices of the Department of Public Health and Engineering (DPHE) provide free well tests, but we do not know how responsive DPHE offices are.

${ }^{33}$ Dupas (2006) finds that information about an easily available alternative to risky behavior results in a significant reduction in the risky behavior in the context of AIDS in Kenya.

${ }^{34}$ The results are available from the authors.
} 
expenditure and assets. Completing between 6 and 10 years of school raises the probability of being informed by 0.2 to 0.29 . Completing more than 10 years of school raises the probability by a further 0.39 to 0.43 for women and a further 0.08 to 0.32 for men. Level of education is likely to be correlated with unobservable characteristics which affect how informed a person is. However, being informed about a health risk may also be a significant return to education.

\section{Conclusion}

Our principal finding is that information alone can rapidly induce a large percentage of people who face a risk to health to change their behavior in order to avoid the risk, even if the change is costly. The important implication is that investment of public resources in providing information can be effective even when resources for a more elaborate intervention, such as alternative sources of water, are lacking.

We provide information about the concentration of arsenic in the water in people's wells. Having an unsafe well increases the probability that the person changes to another well within one year by 0.37 . Furthermore, those who change to another well to avoid arsenic increase the time they spend walking for water fifteen-fold. The response to information is striking since few people were sick from arsenic at the time of our survey and switching to another well is costly.

The crucial effect of our house-to-house information campaign was to provide information specific to the individual, whether her/his well is safe and which wells in the vicinity are safe. Ninetyeight percent of people in our study area know whether their well is safe, while $20 \%$ claim to know in control areas. People exposed only to the media information campaign have not obtained well tests and they have not sought safe water.

The media communicate general information about arsenic no less effectively and less expensively than does the door-to-door campaign. This is surprising since only two-thirds of households own a TV or a radio and few people read newspapers.

The contrast between our results and prior literature raises an important question for future research; under what circumstances is a large and rapid change in behavior in response to information 
likely to occur? One potential explanation is the influence which neighbors have on each others' behavior. If such influence is strong, even if only a few people are convinced of the need to act, their behavior may spread through the community. Such strong effects may help design information campaigns which target only a few people in a group. ${ }^{35}$

Explaining the effect we observe requires understanding which components of our intervention were crucial in eliciting the behavioral response. For example, would a media campaign together with a well test yield the same outcome, or did other parts of our intervention such as the repeated surveys and the daily contact between residents and project staff promote a sense of urgency about the problem? The earth scientists involved in the Araihazar study are documenting the percentage of people who change to another well in areas in which well tests were conducted by the Bangladesh Arsenic Mitigation Water Supply Project in addition to the media campaign. Their data may help to shed light on the question.

A number of questions remain for future research. Future surveys will reveal whether the change in behavior which we document is a long-term or a transitory one. We should understand the long-term impact of the decision to change to another well on welfare, which requires valuing benefits and long term costs such as potentially worse nutrition and/or reduced schooling for children due to reduced income and increased burden of walking for water. Finally, we want to determine whether information can lead to more complex behavioral responses. Access to safe water in the medium and long run is likely to require an organized response by communities, the public sector or the private sector to drill wells into deeper aquifers which are free of arsenic, to pipe water from safe wells, and/or to clean up surface water. The question arises under what conditions an information intervention is sufficient to catalyze collective action.

\footnotetext{
${ }^{35}$ See for example Katz and Lazarsfeld (1955) for a sociological discussion of this idea.
} 


\section{References}

Ahmad, J.K., B.N. Goldar, M. Jakariya, S. Misra, 2002. "Willingness to Pay for Arsenic-free, Safe Drinking Water in Rural Bangladesh - Methodology and Results.” World Bank Report \#25609 Ahsan, H., Y. Chen, F. Parvez, L. Zablotska, M. Argos, I. Hussain, H. Momotaj, D. Levy, Z. Cheng, V. Slavkovich, A. van Geen, G.R. Howe, J.H. Graziano, 2006a. “Arsenic Exposure from Drinking Water and Risk of Premalignant Skin Lesions in Bangladesh: Baseline Results from the Health Effects of Arsenic Longitudinal Study.” American Journal of Epidemiology April 19; [Epub ahead of print] PMID: 16624965 [PubMed - as supplied by publisher]

Ahsan, H., Y. Chen, F. Parvez, M. Argos, I. Hussain, H. Momotaj, D. Levy, A. van Geen, G. Howe, J. Graziano, 2006. "Health Effects of Arsenic Longitudinal Study (HEALS): description of a multidisciplinary epidemiologic investigation.” Journal of Exposure Science and Environmental Epidemiology 16(2): 191-205. PMID: 16160703 [PubMed - in process]

Angrist, J.D., V. Lavy, 1999. “Using Maimonides' Rule to Estimate the Effect of Class Size on Scholastic Achievement." Quarterly Journal of Economics 114(2)

Aziz, Z., A. van Geen, R. Versteeg, A. Horneman, Y. Zheng, S. Goodbred, M. Steckler, M. Stute, B. Weinman, I. Gavrieli, M.A. Hoque, M. Shamsudduha, and K.M. Ahmed, 2006. “Arsenic concentrations in shallow groundwater of Araihazar, Bangladesh: Part II Hydrologic control reflected in the electromagnetic conductivity of soils" submitted to Water Resources Research, January 2006.

British Geological Survey (BGS)/ Department of Public Health and Engineering (DPHE), 2001. Arsenic contamination of groundwater in Bangladesh. Volume 2 - Final Report. Kinniburgh, D.G. and P.L. Smedley, editors. British Geological Survey Technical Report. at http://www.bgs.ac.uk/arsenic/bangladesh/reports.htm.

Bangladesh Rural Advancement Committee, 2000. Combating A Deadly Menace: early experiences with a community-based arsenic mitigation project in Bangladesh, June 1999-June2000. Research Monogaph Series No.16, Dhaka.

Besley, T. and A. Case, 1994. "Diffusion as a Learning Process: Evidence from HYV Cotton.” Working 
paper.

Chang, C.C., S.C. Ho, S.S. Tsai, C.Y. Yang, 2004. "Ischemic Heart Disease Mortality Reduction in an Arseniasis-Endemic Area in Southwestern Taiwan After a Switch in the Tap-Water Supply System." Journal of Toxicology and Environmental Health. 67(17):1353-61.

Chay, K.Y., M. Greenstone, 2005. "Does Air Quality Matter? Evidence from the Housing Market.” Journal of Political Economy 113(2)

Chen, Y, A. van Geen, J. Graziano, M. Madajewicz, A. Pfaff, Z. Cheng, V. Slavkovich, T. Islam, F. Parvez, H. Ahsan, 2006. “The Effectiveness of a Multidisciplinary Community-based Mitigation Program in Reducing Arsenic Exposure in Araihazar, Bangladesh.” Manuscript

Cheng, Z., A. van Geen, C. Jing, X. Meng, A.A. Seddique, K.M. Ahmed, 2004. "Performance of a Household-Level Arsenic Removal System During Four-Month Deployments in Bangladesh." Environmental Science and Technology 38(12).

Chiu, H.F., S.C. Ho, C.Y. Yang, 2004. "Lung Cancer Mortality Reduction After Installation of TapWater Supply System in an Arseniasis-Endemic Area in Southwestern Taiwan." Lung Cancer. 46(3):265-70.

Conley, T. and C. Udry, 2002. "Learning About a New Technology: Pineapple in Ghana.” Working Paper.

Cook, T.D., D.T. Campbell, 1979. Quasi-Experimentation: Design and Analysis Issues for Field Settings. Houghton Mifflin, Boston, chapter 3.

Dehejia, R.H., S. Wahba, 2002. "Propensity Score Matching Methods for Nonexperimental Causal Studies." Review of Economics and Statistics 84(1)

DPHE/BGS/MML, 1999. Groundwater Studies for Arsenic Contamination in Bangladesh. Phase 1:

Rapid Investigation Phase. Six Volumes, British Geological Survey and Mott McDonald Ltd., United Kingdom.

Dupas, P., 2006. "Relative Risks and the Market for Sex: Teenagers, sugar daddies and HIV in Kenya." Manuscript 
Fan, J., 1992. “Design Adaptive Nonparametric Regression.” Journal of the American Statistical Association 87: pp. 998-1004

Foster, A. and M. Rosenzweig, 1995. "Learning by Doing and Learning from Others: Human Capital and Technical Change in Agriculture" Journal of Political Economy 103(6).

Freeman, A.M. III (1993) The Measurement of Environmental and Resource Values: Theory and methods Resources for the Future, Washington, D.C. pp 342 - 351

Grossman, M. (1972) "On the Concept of Health Capital and the Demand for Health" Journal of Political Economy 80(2)

Hahn, J., P. Todd, W. van der Klaauw, 2001. "Identification and Estimation of Treatment Effects with a Regression Discontinuity Design.” Econometrica 69(1)

Heckman, J., H. Ichimura, P. Todd, 1997. "Matching as an Econometric Evaluation Estimator: Evidence from Evaluating a Job Training Programme.” Review of Economic Studies 64(4) , 1998. "Matching as an Econometric Evaluation Estimator." Review of Economic Studies 65(2) Hopenhayn-Rich, C., M.L. Biggs, D.A. Kalman, L.E. Moore, A.H. Smith, 1996. "Arsenic Methylation Patterns Before and After Changing from High to Lower Concentrations of Arsenic in Drinking Water." Environmental Health Perspectives. 104(11):1200-7.

Jalan, J., S. Chaudhuri, E. Somanathan (2005) “Awareness and the Demand for Environmental Quality: Drinking Water in Urban India” Journal of Development Economics forthcoming Katz, E. and P. Lazarsfeld, 1955. Personal Influence: The Part Played by People in the Flow of Mass Communications, New York: Free Press.

Lokuge, K.M., W. Smith, B. Caldwell, K. Dear, A.H. Milton, 2004. "The Effect of Arsenic Mitigation Interventions on Disease Burden in Bangladesh." Environmental Health Perspectives. 112(11):1172-7. McArthur, J.M., P. Ravenscroft, S. Safiullah, M.F. Thirlwall (2001) "Arsenic in groundwater: testing pollution mechanisms for sedimentary aquifers in Bangladesh" Water Resources Research 37(1) Moore, L.E., A.H. Smith, C. Hopenhayn-Rich, M.L. Biggs, D.A. Kalman, M.T. Smith, 1997. "Decrease 
in Bladder Cell Micronucleus Prevalence After Intervention to Lower the Concentration of Arsenic in Drinking Water." Cancer Epidemiology Biomarkers and Prevention. 6(12):1051-6.

Munshi, K. and J. Myaux, 2002. "Social Effects in the Demographic Transition: Evidence from Matlab, Bangladesh” Working Paper, University of Pennsylvania.

Munshi, K., 2004. "Social Learning in a Heterogeneous Population: Technology Diffusion in the Indian Green Revolution" Journal of Development Economics, 73(1).

Nickson R.T., J. McArthur, W.G. Burgess, K. M. Ahmed, P. Ravenscroft, M. Rahman, 1998. “Arsenic Poisoning of Bangladesh Groundwater.” Nature 395: 338

Nickson, R.T., J.M. McArthur, P. Ravenscroft, W.G. Burgess, K.M. Ahmed (2000) "Mechanism of Arsenic Release to Groundwater,Bangladesh and West Bengal" Applied Geochemistry 15: 403-413

Opar, A., A. Pfaff, A.A. Seddique, K.M. Ahmed, J.H. Graziano, A. van Geen, January 9, 2006.

"Responses of 6500 Households to Arsenic Mitigation in Araihazar, Bangladesh." Health and Place, available online

Parvez, F., Y. Chen, M. Argos, A.Z. Hussain, H. Momotaj, R. Dhar, A. van Geen, J.H. Graziano, H.

Ahsan, 2006. "Prevalence of arsenic exposure from drinking water and awareness of its health risks in a Bangladeshi population: results from a large population-based study." Environmental Health Perspectives 114(3): 355-9. PMID: 16507457 [PubMed - in process]

Rice, R. and C. Atkin, eds., 1989. Public Communication Campaigns, Newbury Park: Sage Smith, A.H., E.O. Lingas, and M. Rahman, 2000. "Contamination of drinking-water by arsenic in Bangladesh: a public health emergency". Bulletin of the World Health Organization 78(9):1093. Smith, J., P. Todd, 2001. "Reconciling Conflicting Evidence on the Performance of Propensity-Score Matching Methods.” American Economic Review 91(2)

Stute, M., Y. Zheng, P. Schlosser, A. Horneman, R.K. Dhar, M. A. Hoque, A. A. Seddique, M.

Shamsudduha, K. M. Ahmed, and A. van Geen, 2006. "Hydrological control of As concentrations in Bangladesh groundwater" revision sent to Water Resources Research, February 2006.

Valente, T. and W. Saba, 1998. "Mass Media and Interpersonal Influence In a Reproductive Health 
Communication Campaign in Bolivia” Communication Research 25: 96-124.

van Geen, A., H. Ahsan, A.H. Horneman, R.K. Dhar, Y. Zheng, I. Hussain, K.M. Ahmed, A. Gelman, M.

Stute, H.J. Simpson, S. Wallace, C. Small, F. Parvez, V. Slavkovich, N.J. Lolocano, M. Becker, Z.

Cheng, H. Momotaj, M. Shahnewaz, A.A. Seddique, J.H. Graziano, 2002. "Promotion of wellswitching to mitigate the current arsenic crisis in Bangladesh". Bulletin of the WHO. 80:732-737.

van Geen, A., K.M. Ahmed, A.A. Seddique, M. Shamsudduha, 2003. "Community Wells to Mitigate the Arsenic Crisis in Bangladesh." Bulletin of the WHO. 81:632-638.

van Geen, A., Y. Zheng, R. Versteeg, M. Stute, A. Horneman, R. Dhar, M. Steckler, A. Gelman, C.

Small, H. Ahsan, J. Graziano, I. Hussein, and K. M. Ahmed, 2003. "Spatial variability of arsenic in 6000 tube wells in a $25 \mathrm{~km} 2$ area of Bangladesh" Water Resources Research, 39(5)

Wasserman, G.A., X. Liu, F. Parvez, H. Ahsan, P. Factor-Litvak, A. van Geen, Z. Cheng, V. Slavkovich, Hussain, H. Momotaj, J. H. Graziano, 2004. “Water arsenic exposure and children’s intellectual function in Araihazar, Bangladesh" Environmental Health Perspectives, 112: 1329-1333.

Weinman, B., S.L. Goodbred, Y. Zheng, Z. Aziz, A.K. Singhvi, Y.C. Nagar, M. Steckler, A. van Geen, “Arsenic Concentrations in Shallow Groundwater of Araihazar, Bangladesh: Part I. Geological control through floodplain evolution." Submitted to Water Resources Research

Wooldridge, J.M., 2002. Econometric Analysis of Cross Section and Panel Data The MIT Press, Cambridge, M.A., London, England

World Bank, 2000. World Development Report 2000/2001. Oxford University Press, Oxford, 335p.

World Health Organization,1995. The World Health Report: Bridging the Gap. World Health Organization, Geneva.

World Health Organization/International Red Cross, 1997. "Linking Technology Choice for Operation and Maintenance for Low-Cost Water Supply and Sanitation”. Operation and Maintenance Working Group of the WSSCC (Water Supply and Sanitation Collaborative Council). IRC International Water and Sanitation Center, The Hague.

World Health Organization, 1999. The World Health Report. World Health Organization, Geneva. 
World Health Organization, 2000. Towards an Assessment of the Socioeconomic Impact of Arsenic Poisoning in Bangladesh. Protection of the Human Environment: Water, Sanitation and Health Report, Geneva.

Water Supply and Sanitation Collaborative Council (WSSCC), 1999. Vision 21: A Shared Vision for water supply, Sanitation and Hygiene and a Framework for Future Action. Water Supply and Sanitation Collaborative Council, Geneva. 


\section{Table 1: Descriptive statistics for Araihazar data}

\begin{tabular}{lcccc}
\hline Variable & Mean & Std. Dev. & Min & Max \\
\hline Arsenic level (micrograms/liter) & 108 & 119 & 5 & 879 \\
Well is safe (takes value 1 if arsenic $\leq 50)^{\mathrm{a}}$ & 0.43 & 0.50 & 0 & 1 \\
Changed to another well for drinking water & 0.40 & 0.49 & 0 & 1 \\
Distance to original well (minutes walking) & 0.13 & 0.5 & 0 & 6 \\
Distance to new well (minutes walking) & 1.05 & 2.26 & 0 & 20 \\
Change in walking time due to change of well & 0.93 & 2.26 & -5 & 20 \\
Age of respondent & 37 & 11 & 16 & 80 \\
Respondent is female & 0.56 & 0.50 & 0 & 1 \\
Number of people in household & 5.8 & 2.3 & 2 & 24 \\
Can read and write & 0.45 & 0.50 & 0 & 1 \\
Highest grade completed was at primary level & 0.24 & 0.43 & 0 & 1 \\
Highest grade completed was at secondary level & 0.22 & 0.42 & 0 & 1 \\
Highest grade completed was at higher level & 0.03 & 0.17 & 0 & 1 \\
Attend religious services: 1-never, 2-few times/year, & 2.83 & 1.51 & 1 & 5 \\
3-every month, 4-every week, 5-every day & 17 & 17 & 0 & 250 \\
Number of relatives who live in the area & & & & \\
\hline
\end{tabular}

${ }^{\text {a }}$ Seventy-seven percent of wells in Araihazar have arsenic concentrations which exceed the stricter WHO standard of 10 micrograms per liter. 
Table 2: Comparison of Araihazar and control areas

\begin{tabular}{|c|c|c|c|c|c|c|}
\hline & Araihazar & $\begin{array}{c}\text { Control } \\
\text { areas }\end{array}$ & Ghior & Jessore & Nikli & Tangail \\
\hline$\%$ of unsafe wells ${ }^{\mathrm{a}}$ & 56.8 & 34.9 & 30.4 & 26.4 & 12.9 & 63.3 \\
\hline \multirow[t]{2}{*}{ Years of education* } & 3.18 & 5.34 & 4.5 & 7.26 & 2.83 & 4.88 \\
\hline & $(0.07)$ & $(0.15)$ & $(0.30)$ & $(0.21)$ & $(0.27)$ & $(0.35)$ \\
\hline Monthly per capita & 1,363 & 1,336 & 1,162 & 1,473 & 927 & 1,560 \\
\hline $\begin{array}{l}\text { household expenditure } \\
\text { (taka) }\end{array}$ & (32.13) & $(55)$ & (134) & $(82)$ & (57) & (159) \\
\hline $\begin{array}{l}\text { Per capita household } \\
\text { assets* (taka) }\end{array}$ & $\begin{array}{l}73,097 \\
(4,188)\end{array}$ & $\begin{array}{l}136,781 \\
(8,659)\end{array}$ & $\begin{array}{c}81,171 \\
(12,270)\end{array}$ & $\begin{array}{l}151,617 \\
(11,840)\end{array}$ & $\begin{array}{l}53,476 \\
(5,121)\end{array}$ & $\begin{array}{l}246,383 \\
(32,068)\end{array}$ \\
\hline Days of work or & 13.82 & 17.07 & 10.43 & 18.23 & 19.02 & 24.91 \\
\hline $\begin{array}{l}\text { school missed due to } \\
\text { illness last year* }\end{array}$ & $(0.66)$ & $(0.91)$ & $(1.49)$ & $(1.37)$ & (1.69) & $(5.59)$ \\
\hline Fraction use own & 0.34 & 0.63 & 0.35 & 0.89 & 0.21 & 0.73 \\
\hline well* & $(0.009)$ & $(0.02)$ & $(0.03)$ & $(0.02)$ & $(0.03)$ & $(0.03)$ \\
\hline Fraction use well in & 0.47 & 0.13 & 0.34 & 0.07 & 0.06 & 0.1 \\
\hline bari* & $(0.01)$ & $(0.01)$ & $(0.03)$ & $(0.01)$ & $(0.02)$ & $(0.02)$ \\
\hline Fraction use & 0.01 & 0.11 & 0.04 & 0.02 & 0.48 & 0.06 \\
\hline community well* & $(0.002)$ & $(0.01)$ & $(0.01)$ & $(0.007)$ & $(0.04)$ & $(0.02)$ \\
\hline Hours watch & 27.06 & 35.03 & 22.84 & 56.24 & 17.15 & 23.58 \\
\hline television per month* & $(0.75)$ & $(1.3)$ & $(2.08)$ & $(2.45)$ & $(1.92)$ & $(1.7)$ \\
\hline Hours listen to radio & 8.63 & 18.69 & 15.61 & 25 & 18.22 & 10.28 \\
\hline per month* & $(0.37)$ & $(0.9)$ & $(1.78)$ & $(1.71)$ & $(1.98)$ & $(1.1)$ \\
\hline Days read newspaper & 2.48 & 7.11 & 3.87 & 12.05 & 1.94 & 6.06 \\
\hline per month* & $(0.14)$ & $(0.36)$ & $(0.63)$ & $(0.66)$ & $(0.43)$ & $(0.77)$ \\
\hline $\begin{array}{l}\text { Number of } \\
\text { observations }\end{array}$ & 2680 & 997 & 199 & 397 & 201 & 200 \\
\hline
\end{tabular}

Table reports means. Standard errors of the sample mean estimate are in parentheses.

* Asterisks denote variables whose means are different for Araihazar and for control areas at a level of significance of 0.05 . We have not conducted a mean comparison test for levels of arsenic.

${ }^{a}$ The percentage for Araihazar is from our own data. Percentages for control areas come from UNICEF and are based on a sample of wells from each district: 11,000 wells in Ghior, 35,000 in Jessore, 10,000 in Nikli and 20,000 in Tangail.

${ }^{\mathrm{b}}$ These are the total numbers of observations. Not all observations are used to calculate the mean for each variable since different variables have different numbers of missing values. 
Table 3: Determinants of whether a well is safe or not

\begin{tabular}{|c|c|c|c|}
\hline & & & Dependent variable \\
\hline & $\begin{array}{c}\text { Mean for those with } \\
\text { safe wells }\end{array}$ & $\begin{array}{c}\text { Mean for those with } \\
\text { unsafe wells }\end{array}$ & $\begin{array}{c}\text { Is well safe? } \\
\text { (1 if yes) }\end{array}$ \\
\hline & & & OLS $^{\text {ab }}$ \\
\hline Years of education & 3.23 & 3.13 & - \\
\hline & $\mathrm{p}$ value for mean test & 0.48 & \\
\hline Primary education & - & - & .02 \\
\hline ( 1 if yes) & & & $(.025)$ \\
\hline Secondary education & - & - & .04 \\
\hline (1 if yes) & & & $(.029)$ \\
\hline Higher education & - & - & -.004 \\
\hline (1 if yes) & & & $(.053)$ \\
\hline Monthly household & 8399 & 7230 & - \\
\hline expenditure (taka) & $p$ value for mean test & 0.002 & \\
\hline $2^{\text {nd }}$ quartile of & - & - & .02 \\
\hline expenditure (binary) & & & $(.029)$ \\
\hline $3^{\text {rd }}$ quartile of & - & - & .03 \\
\hline expenditure (binary) & & & $(.032)$ \\
\hline $4^{\text {th }}$ quartile of & - & - & .001 \\
\hline expenditure (binary) & & & $(.036)$ \\
\hline Household assets & 533,660 & 376,352 & - \\
\hline (taka) & $p$ value for mean test & 0.06 & \\
\hline $2^{\text {nd }}$ quartile of assets & - & - & .02 \\
\hline (binary) & & & $(.029)$ \\
\hline $3^{\text {rd }}$ quartile of assets & - & - & .02 \\
\hline (binary) & & & $(.032)$ \\
\hline $4^{\text {th }}$ quartile of assets & - & - & .04 \\
\hline (binary) & & & $(.034)$ \\
\hline Own baseline well & .36 & .33 & .04 \\
\hline (1 if used one) & $p$ value for mean test & 0.12 & $(.037)$ \\
\hline Baseline well in bari & .45 & .48 & -.02 \\
\hline (1 if used one) & $p$ value for mean test & 0.22 & $(.033)$ \\
\hline Number of relatives & 18 & 16.6 & -.0007 \\
\hline in the area & $p$ value for mean test & 0.03 & $(.0005)$ \\
\hline Days missed because & 13.44 & 14.04 & -.00003 \\
\hline of illness last year & $\mathrm{p}$ value for mean test & 0.66 & $(.0003)$ \\
\hline Age & 36.5 & 37.3 & $-.002 *$ \\
\hline & $p$ value for mean test & 0.06 & $(.001)$ \\
\hline Village fixed effects & - & - & Yes \\
\hline $\mathrm{N}$ & - & - & 2097 \\
\hline $\mathrm{R}^{2}$ & - & - & .35 \\
\hline$p$ value for $F$ test & - & - & .00 \\
\hline
\end{tabular}

${ }^{a}$ Robust standard errors clustered by baseline well are in parentheses. Other independent variables in the regression are how often attend religious services, how far walk to baseline well, household size. Their coefficients and the differences in means are not significant. Continuous education, expenditures and assets are also not significant if used instead of the binary categories. Results with respect to significance levels are the same in a probit regression. ${ }^{\mathrm{b}}$ The $\mathrm{F}$ test for the $\mathrm{H}_{0}$ that coefficients on all independent variables except the village fixed effects are zero has a $\mathrm{p}$ value of 0.33 .

$* *$ denotes significance at $0.05 . *$ denotes significance at 0.1 . 
Table 4: Response to information that well is unsafe

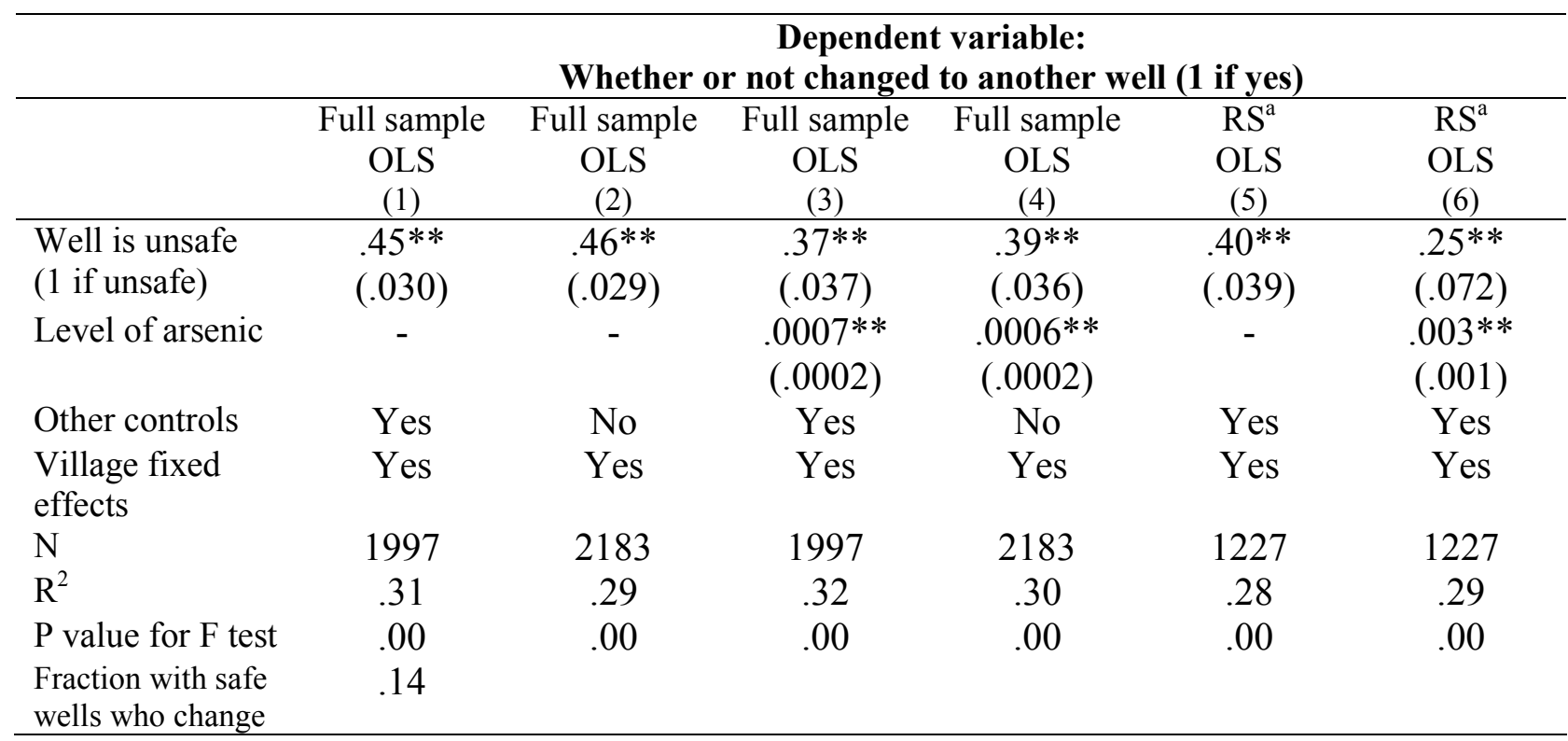

Robust standard errors clustered by baseline well are in parentheses.

Other independent variables in regressions in columns 1,3,5 and 6 are percent of neighbors who live within 100 meters whose wells are unsafe, average arsenic level in wells of neighbors who live within 100 meters, education, monthly household expenditure, household assets, whether used own baseline well, whether used baseline well in bari, how long walked to baseline well, days missed due to illness last year, number of relatives in the area, how often attend religious services, household size, age.

Other independent variables in regressions in columns 2 and 4 are percent of neighbors who live within 100 meters whose wells are unsafe and average arsenic level in wells of neighbors who live within 100 meters. The estimate values change very little if we exclude these two controls.

${ }^{a}$ The column reports a regression on a restricted sample (RS), which consists of households whose baseline wells have arsenic levels between $0 \mu \mathrm{g} / \mathrm{L}$ and $100 \mu \mathrm{g} / \mathrm{L}$.

$* *$ denotes significance at 0.05 . ${ }^{*}$ denotes significance at 0.1 . 


\section{Table 5: Impact of changing to a different well on additional time spent walking for water and on monthly household expenditures}

\begin{tabular}{|c|c|c|c|c|c|c|c|c|}
\hline & \multicolumn{6}{|c|}{$\begin{array}{c}\text { Dependent variable: } \\
\text { time to current well minus time to baseline well }{ }^{\mathrm{a}}\end{array}$} & \multicolumn{2}{|c|}{$\begin{array}{l}\text { Dependent variable: } \\
\text { log of per capita } \\
\text { monthly expenditure }\end{array}$} \\
\hline & $\begin{array}{l}\text { Full } \\
\text { sample } \\
\text { OLS } \\
(1)\end{array}$ & $\begin{array}{c}\text { Full } \\
\text { sample } \\
\text { RF }^{\mathrm{d}} \\
(2)\end{array}$ & $\begin{array}{c}\text { Full } \\
\text { sample } \\
\text { IV } \\
\text { (3) }\end{array}$ & $\begin{array}{l}\mathrm{RS}^{\mathrm{c}} \\
\mathrm{OLS} \\
(4)\end{array}$ & $\begin{array}{l}\mathrm{RS}^{\mathrm{c}} \\
\mathrm{RF}^{\mathrm{d}} \\
(5)\end{array}$ & $\begin{array}{l}\mathrm{RS}^{\mathrm{c}} \\
\mathrm{IV} \\
(6)\end{array}$ & $\begin{array}{c}\text { Full } \\
\text { sample } \\
\text { OLS } \\
(7)\end{array}$ & $\begin{array}{l}\text { Full } \\
\text { sample } \\
\text { IV } \\
(8)\end{array}$ \\
\hline $\begin{array}{l}\text { Whether or not } \\
\text { changed ( } 1 \text { if yes) }\end{array}$ & $\begin{array}{l}1.52^{* *} \\
(.124)\end{array}$ & - & $\begin{array}{l}2.15^{* *} \\
(.258)\end{array}$ & $\begin{array}{l}.93^{* *} \\
(.164)\end{array}$ & - & $\begin{array}{l}1.82^{* *} \\
(.346)\end{array}$ & $\begin{array}{l}.009 \\
(.032)\end{array}$ & $\begin{array}{c}0.03 \\
(.074)\end{array}$ \\
\hline $\begin{array}{l}\text { Whether well is } \\
\text { unsafe ( } 1 \text { if unsafe) }\end{array}$ & - & $\begin{array}{l}.68 * * \\
(.152)\end{array}$ & - & - & $\begin{array}{c}.29 \\
(.255)\end{array}$ & - & - & - \\
\hline Level of arsenic & - & $\begin{array}{l}.002 * * \\
(.0009)\end{array}$ & - & - & $\begin{array}{l}.009 * * \\
(.004)\end{array}$ & - & - & - \\
\hline Other controls & Yes & Yes & Yes & Yes & Yes & Yes & Yes & Yes \\
\hline Village fixed effects & Yes & Yes & Yes & Yes & Yes & Yes & Yes & Yes \\
\hline $\mathrm{N}$ & 1994 & 1995 & 1994 & 1225 & 1226 & 1225 & 1975 & 1975 \\
\hline $\mathrm{R}^{2}$ & .22 & .16 & .20 & .13 & .11 & .09 & .36 & .36 \\
\hline$P$ value for $F$ test & .00 & .00 & .00 & .00 & .00 & .00 & .00 & .00 \\
\hline $\begin{array}{l}\text { Mean additional minutes to } \\
\text { well for households with } \\
\text { safe baseline wells } \\
\text { Mean of log monthly } \\
\text { expenditures for households } \\
\text { with safe baseline wells }\end{array}$ & .22 & & & & & & 8.74 & \\
\hline
\end{tabular}

Robust standard errors clustered by baseline well are in parentheses.

${ }^{a}$ Other controls in these regressions are percent of neighbors who live within 100 meters whose wells are unsafe, average arsenic level in wells of neighbors who live within 100 meters, education, monthly household expenditure, household assets, whether used own baseline well, whether used baseline well in bari, how long walked to baseline well, days missed due to illness last year, number of relatives in the area, how often attend religious services, household size, age.

${ }^{\mathrm{b}}$ Other controls in these regressions are percent of neighbors who live within 100 meters whose wells are unsafe, average arsenic level in wells of neighbors who live within 100 meters, education, household assets, whether used own baseline well, whether used baseline well in bari, how long walked to baseline well, days missed due to illness last year, number of relatives in the area, how often attend religious services, household size, age.

${ }^{\mathrm{c}}$ The column reports a regression on a restricted sample (RS), which consists of households whose baseline wells have arsenic levels between $0 \mu \mathrm{g} / \mathrm{L}$ and $100 \mu \mathrm{g} / \mathrm{L}$.

${ }^{\mathrm{d}}$ Reduced form OLS regression.

** denotes significance at $0.05 . *$ denotes significance at 0.1 . 
Table 6: Effect of information campaign in Araihazar on being informed

\begin{tabular}{|c|c|c|c|c|c|c|c|c|c|}
\hline & \multicolumn{9}{|c|}{ Dependent variable } \\
\hline & \multicolumn{3}{|c|}{$\begin{array}{c}\text { Is aware of arsenic } \\
\text { (1 if yes) }\end{array}$} & \multicolumn{3}{|c|}{$\begin{array}{l}\text { Knows that boiling does not } \\
\text { remove arsenic ( } 1 \text { if yes) }\end{array}$} & \multicolumn{3}{|c|}{$\begin{array}{c}\text { Knows that arsenicosis is } \\
\text { not contagious } \\
(1 \text { if yes })\end{array}$} \\
\hline & $\begin{array}{l}\text { Mean } \\
\text { diff. }^{\text {a }} \\
(1)\end{array}$ & $\begin{array}{l}\mathrm{OLS}^{\mathrm{b}} \\
(2) \\
\end{array}$ & $\begin{array}{l}\text { Propensity } \\
\text { score }^{\mathrm{c}} \\
(3)\end{array}$ & $\begin{array}{c}\text { Mean } \\
\text { diff. }^{\text {a }} \\
(4)\end{array}$ & $\begin{array}{l}\mathrm{OLS}^{\mathrm{b}} \\
(5) \\
\end{array}$ & $\begin{array}{l}\text { Propensity } \\
\text { score }^{\mathrm{c}} \\
(6)\end{array}$ & $\begin{array}{l}\text { Mean } \\
\text { diff. }^{\text {a }} \\
(7)\end{array}$ & $\mathrm{OLS}^{\mathrm{b}}$ & $\begin{array}{l}\text { Propensity } \\
\text { score }^{c} \\
(9)\end{array}$ \\
\hline & $\begin{array}{l}.15^{* *} \\
(.00)\end{array}$ & - & - & $\begin{array}{c}-.10^{* *} \\
(.00)\end{array}$ & - & - & $\begin{array}{l}-.17 * * \\
(.00)\end{array}$ & - & - \\
\hline $\begin{array}{l}\text { Resides in } \\
\text { Araihazar } \\
\text { (1 if yes) }\end{array}$ & - & $\begin{array}{l}.20^{* *} \\
(.009)\end{array}$ & $\begin{array}{l}.20 * * \\
(.025)\end{array}$ & - & $\begin{array}{l}-.005 \\
(.023)\end{array}$ & $\begin{array}{c}-.03 \\
(.032)\end{array}$ & - & $\begin{array}{l}-.07 * * \\
(.023)\end{array}$ & $\begin{array}{l}-.10^{* *} \\
(.036)\end{array}$ \\
\hline $\begin{array}{l}\text { Other } \\
\text { controls }\end{array}$ & - & Yes & Yes & - & Yes & Yes & - & Yes & Yes \\
\hline $\begin{array}{l}\text { Village } \\
\text { fixed effects }\end{array}$ & - & No & No & - & No & No & - & No & No \\
\hline $\mathrm{N}$ & 3648 & 3221 & $\begin{array}{c}\text { Treat: } 2384 \\
\text { Control: } 562\end{array}$ & 3462 & 3063 & $\begin{array}{c}\text { Treat: } 2384 \\
\text { Control: } 458\end{array}$ & 3457 & 3061 & $\begin{array}{l}\text { Treat: } 2384 \\
\text { Control: } 460\end{array}$ \\
\hline $\begin{array}{l}\mathrm{R}^{2} \\
\mathrm{p} \text { value for } \mathrm{F} \\
\text { test }\end{array}$ & $\begin{array}{l}- \\
-\end{array}$ & $\begin{array}{l}.16 \\
.00\end{array}$ & $\begin{array}{l}- \\
-\end{array}$ & $\begin{array}{l}- \\
-\end{array}$ & $\begin{array}{l}.09 \\
.00\end{array}$ & $\begin{array}{l}- \\
-\end{array}$ & - & $\begin{array}{l}.11 \\
.00\end{array}$ & $\begin{array}{l}- \\
-\end{array}$ \\
\hline $\begin{array}{l}\text { The values in } t \\
\text { know in control } \\
{ }^{b} \text { Standard error } \\
\text { household expe } \\
\text { TV and listen to } \\
\text { c The approach } \\
\text { parentheses. Th } \\
\text { control areas we } \\
\text { are household s } \\
\text { live in the area, } \\
\text { household asset } \\
\text { ** denotes sign }\end{array}$ & $\begin{array}{l}\text { S colum } \\
\text { reas. P } \\
\text { are in pa } \\
\text { liture, ho } \\
\text { adio, ho } \\
\text { nearest } \\
\text { estimati } \\
\text { outside } \\
\text { e and th } \\
\text { ducation } \\
\text { and two } \\
\text { cance at }\end{array}$ & $\begin{array}{l}\text { are diff } \\
\text { ue of t } \\
\text { nthese } \\
\text { sehold } \\
\text { many } \\
\text { ighbor } \\
\text { uses o } \\
\text { he com } \\
\text { highe } \\
\text { nd five } \\
\text { gher or }\end{array}$ & $\begin{array}{l}\text { nces betweer } \\
t \text { is in parentl } \\
\text { he other con } \\
\text { ets, religious } \\
\text { s read newsp } \\
\text { tching with } \\
\text { observations } \\
\text { n support reg } \\
\text { der terms, ag } \\
\text { gher order ter } \\
\text { r terms. } \\
\text { otes significa }\end{array}$ & $\begin{array}{l}\text { e perce } \\
\text { es. } \\
\text { ls are h } \\
\text { endanc } \\
\text { ens. } \\
\text { al weig } \\
\text { the reg } \\
\text { h. Varia } \\
\text { ind two } \\
\text { montl }\end{array}$ & $\begin{array}{l}\text { age wh } \\
\text { sehold } \\
\text { numbe } \\
\text { s in cas } \\
\text { n of ov } \\
\text { les incl } \\
\text { igher or } \\
\text { housel }\end{array}$ & $\begin{array}{l}\text { now in Araih } \\
\text { e, age, gende } \\
\text { f relatives in } \\
\text { f a tie. Boots } \\
\text { apping suppo } \\
\text { d in the calcu } \\
r \text { terms, gend } \\
\text { d expenditure }\end{array}$ & $\begin{array}{l}\mathrm{r} \text { and } \mathrm{p} \\
\text { ducatio } \\
\text {, how } \\
\text { ped st } \\
\text { Eight o } \\
\text { on of } t \\
\text { numbe } \\
d \text { three }\end{array}$ & $\begin{array}{l}\text { centage v } \\
\text { monthly } \\
\text { any hours } \\
\text { dard errol } \\
\text { ervations } \\
\text { propensi } \\
\text { f relative } \\
\text { gher ord }\end{array}$ & $\begin{array}{l}\text { watch } \\
\text { are in } \\
\text { in } \\
\text { y score } \\
\text { who } \\
\text { r terms, }\end{array}$ \\
\hline
\end{tabular}




\section{Figure 1}

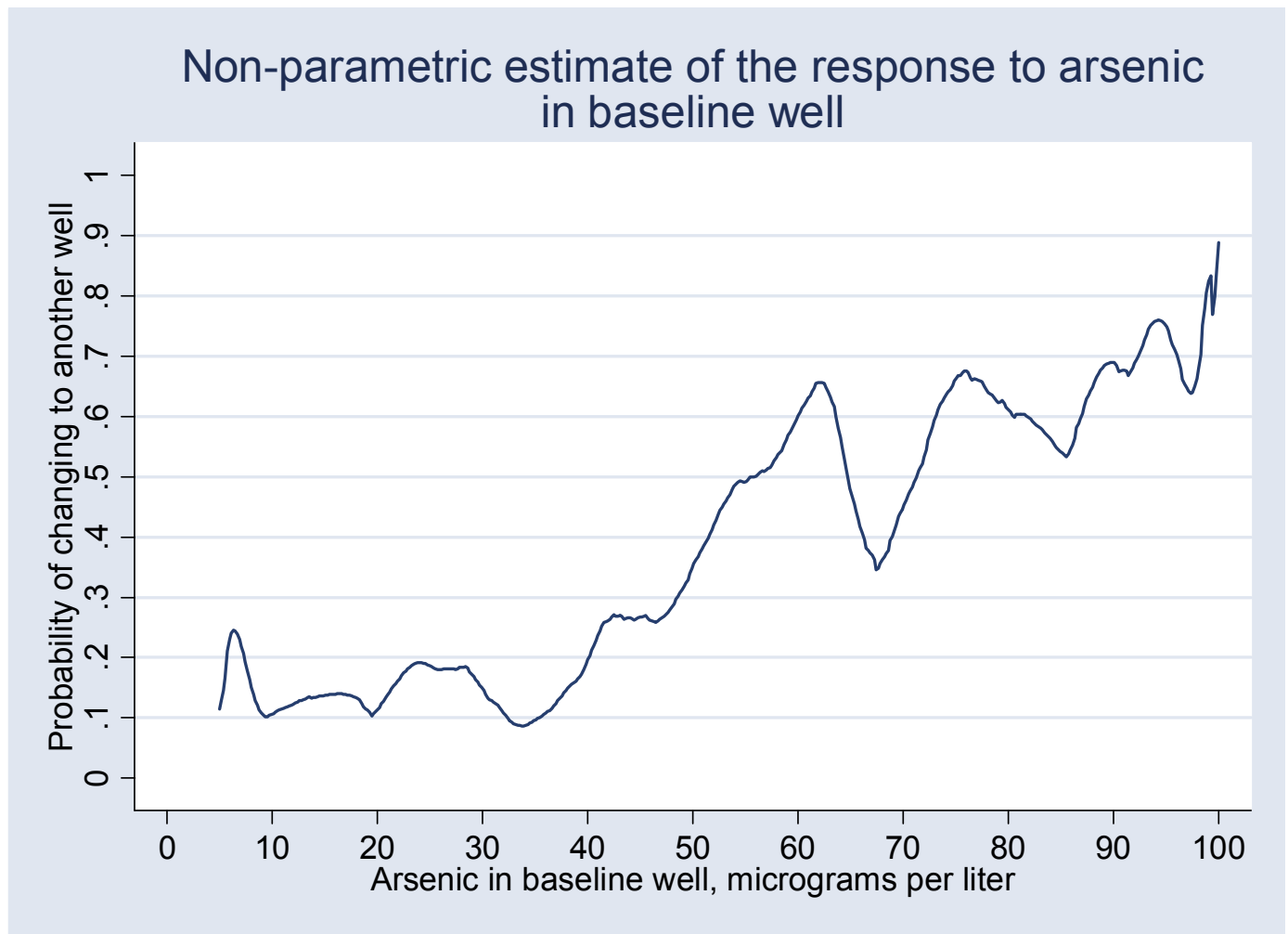

The plot shows the probability of changing estimated using a kernel-weighted (Epanechnikov kernel) local polynomial approximation. The approach is recommended by Hahn et al (2001) and presented in Fan (1992). 


\section{Figure 2}

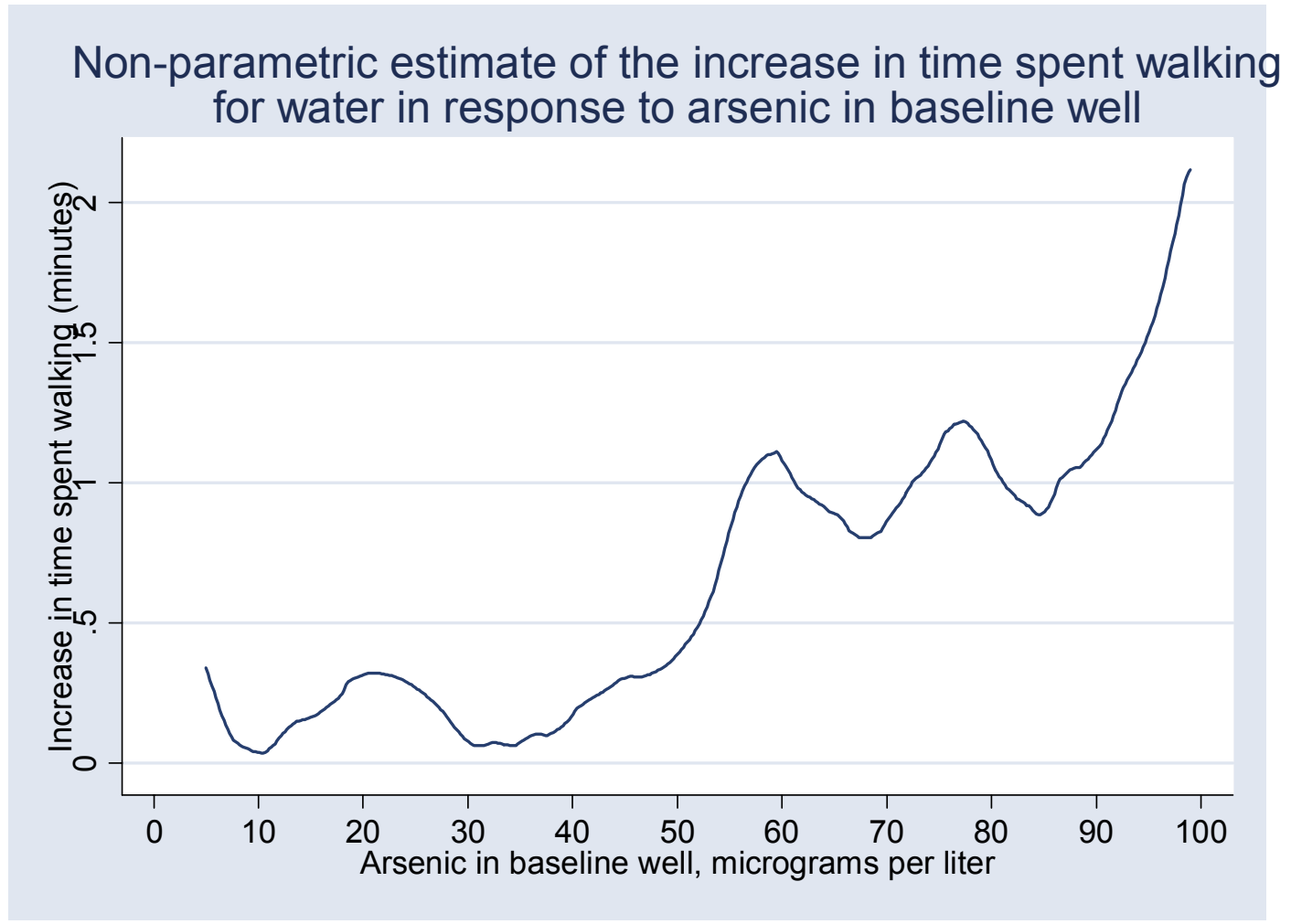

The plot shows the increase in the time spent walking estimated using a kernel-weighted (Epanechnikov kernel) local polynomial approximation. The approach is recommended by Hahn et al (2001) and presented in Fan (1992). 


\section{Appendix}

\section{A.1 Time line of our project}

Year 2000: $\quad$ Baseline survey documents all wells in the study area and asks a random sample of people whether they have heard of arsenic

Years 2001 -2002: $\quad$ 1) Project tests and labels all wells

2) Contemporaneously with \#1, public health team conducts physical exams, communicates well test result, and asks whether respondent knows about arsenic for a random sample of married couples. People have not begun to switch to other wells yet, but they have been exposed to project staff for over a year, thereby learning about arsenic.

3) Following the public health interviews, a team of educators travels around the area, summons people to a meeting in each neighborhood and conveys a number of facts about arsenic poisoning. Meetings are on weekdays, during the day.

4) Six to twelve months after the team of educators has been to a particular area, we conduct a survey of a random sample of those individuals interviewed by the public health team in $\# 2$. We document whether they have changed to another well, what they know about the arsenic problem and collect socio-economic data. All socio-economic data are from this survey.

Year 2002: Surveys of households in control areas occur before NGOs have started their information campaigns. No systematic well tests have been done except those conducted by UNICEF on a small sample of wells, which were chosen independently of our sample. We ask questions about the well which people were using 12 months ago, i.e. at the time when well tests were being conducted in Araihazar and what they knew about arsenic then. We also ask whether people have changed to another well during the last twelve months, what they know about arsenic now, and collect socio-economic data. 


\section{A.2 Health effects of arsenic ${ }^{36}$}

The effects of arsenic are cumulative. Up to a point, effects can be reversed if exposure to arsenic ceases. However, even complete elimination of exposure cannot reverse the changes in health after a sufficiently long period of exposure.

Keratosis has the earliest onset, with a gestation period of 5 to 15 years. It has a number of symptoms. The most common ones are a darkening of the pigmentation of the skin, and a hardening of the skin on the palms and the feet. As the hardening progresses, the flesh may crack, gangrene may set in, and the victim may lose her limbs. The spots of darkened pigmentation may eventually become cancerous.

Continued exposure to arsenic can affect most organs in the body. It can lead to liver, lung, kidney and bladder malfunctions. It can cause hypertension, strokes and heart disease. Eventually, it leads to a number of types of cancer.

Arsenic exposure can also lead to developmental problems in children.

\footnotetext{
${ }^{36}$ Please see footnote 3 for references relevant for this section.
} 